УДК 80

DOI: 10.33184/YVDK-2021-04-30.38

А.А. Бен Шушан (доц. БашГУ, г. Уфа)

\title{
РЕЧЕВЫЕ АКТЫ ЗАПРЕТА, ОПРОВЕРЖЕНИЯ И НЕОДОБРЕНИЯ В ЭМПАТИЧЕСКОМ ОБЩЕНИИ
}

«Эмпатия - основа нашего соучастия в переживаниях другого - сочувствия, а также со-думания, содействия...» К. Роджерс

Аннотация. В статье рассматриваются речевые акты негации реагирующего адресата в эмпатических высказываниях сферы сопереживания. Речевые акты негативной реакиии представлены иллокутивными типами «запрет», «опровержение» $u$ «неодобрение». Определяется специфика реализации высказываний отрицательной реакции в ситуации эмпатического общения в русском и франиузском языках.

Ключевые слова: вербальная эмпатия, негативная реакичя, директив, репрезентатив, речевой акт запрета, неодобрение, опровержение.

The article deals with the speech acts of negation of the reacting addressee in the empathic statements of the sphere of empathy. The research also reveals the specificity of negative reaction utterances in the situation of empathic communication in Russian and French languages.

Key Words: verbal empathy, negative reaction, directive speech acts, representational speech acts, prohibition, disapproval, refutation.

В современном обществе, когда люди все чаще общаются с электронными устройствами, чем друг с другом, остро стоит вопрос в духовно-этической ориентации межличностного общения, а именно, эмпатической коммуникации. Эмпатия проявляется в способности коммуникантов воспринимать участников интеракции как объект сопереживания в речевой ситуации связанной с негативными событиями, или как объект сорадования, в позитивной ситуации общения. Кроме этого 
эмпатическое соучастие в беседе является эффективным инструментом успешной межличностной коммуникации.

В процессе эмпатической интеракции эмпатия способна проявлять себя вербально в виде речевых актов, представляющих две сферы эмпатии: сопереживание и сорадование [Кузнецова 2010]. Сфера сопереживания вербальной эмпатии включает речевые акты класса экспрессивов (соболезнование, сочувственное понимание, сожаление), а также речевые акты утешения на основе классификации Л.А. Азнабаевой речевых актов психологической поддержки адресата (успокоение, ободрение, оправдание, разубеждения) [Азнабаева 2005]. В современных исследованиях выделяют также ситуативные речевые тактики эмпатической направленности, включенные в сферу сопереживания, такие как тактика позитивного прогноза «Во благо», «Все пройдет», а также утешающая тактика поправимости любой негативной ситуации «Это не конец всему».

Интересным на наш взгляд представляется тот факт, что среди эмпатийных речевых актов сферы сопереживания выделяются речевые акты негащии или негативной реакции, которым принадлежит важная роль в создании эмпатийного межличностного взаимодействия. Основным прагматическим намерением высказываний отрицательной заряженности [Трофимова 2008] является выражение неприятия, отклонение или коррекция мнения эмпатируемого коммуниканта с целью утешающего эффекта. При этом, под выражением отрицательного отношения, чувств и эмоций может скрываться маскировка манипулятивного поведения.

Речевой акт негации представляет собой особое речевое действие, отличное от соответствующего утвердительного, акт, проявляющий себя в оппозиции «утверждение - отрицание». Формально-грамматическим показателем структуры негации выступает отрицательный компонент.

В речи маркированность отрицательных высказываний больше всего проявляется в прагматических пресуппозициях, когда говорящий употребляет отрицательные конструкции в эмпатийных высказываниях только тогда, когда он уверен или предполагает, что его пресуппозиция высказывания уже известна собеседнику и создает тот фон, те общие знания, по отношению к 
которым отрицательное высказывание может быть использовано как уместное [Переяшкина 2015]. Рассмотрим некоторые из них.

В межличностном общении в качестве эмпатической реакции на сообщение адресанта о жизненных трудностях может выступать речевой акт запрета, который относится к числу директивных (побудительных) высказываний категоричного характера.

Как правило, отсутствие определенного перформативного глагола директивных высказываний не мешает запрещению быть реализованным эксплицитно, при помощи прямого акта запрета в императивной форме.

Например, в ситуации, когда школьник описывает, как он страдает из-за того, что не смог сдать выпускной экзамен, реагирующий адресат предпринимает попытку утешить собеседника при помощи прескриптивного речевого акта запрета:

(Адресант)

-Кажется, я один не смог списать в классе. Я неудачник.... Очень волнуюсь о будущем, что я буду делать если не сдам? Каждый день плачу...

(Адресат)

-Никаких дурных мыслей, даже не допускай!

Категоричная форма предает высказыванию уверенность говорящего в том, что негативные мысли горюющего усугубят его эмоциональное состояние, и что их необходимо исключить. Иллоктивным намерением высказывания, требующего, чтобы адресат не думал о плохом, является проявление эмпатической заботы и оказание психологической поддержки адресату.

Многие исследователи рассматривают речевой акт запрета в качестве коррелята приказа в отрицательной форме (отрицательного или негативного приказа) [Руссинова 2006: 14], суть которого заключается в том, что говорящий каузирует адресата не совершать или прекратить уже начатое к моменту речи нежелательное для говорящего действие (вербальное или невербальное) [Боргер 2004].

В той же речевой ситуации:

(Адресат)

-Перестаньте! Не настраивайтесь негативно! 
Во французском языке побуждение эмпатирующего не думать негативно обладает «нейтральным» оттенком и приобретает суггестивную форму дружественного совета:

(Адресат)

-Ne pensez pas au mal, arrêtez d'être triste! Pensez au bien, vos pensées créent votre vie / Не думайте о плохом, перестаньте грустить! Ваши мысли создают вашу жизнь.

Прагматическим параметром речевого акта совета выступает отсутствие облигаторности. Отрицательный совет сменяется положительным, способствуя созданию позитивного эмоционального настроя собеседника, а также помогает эффективно справиться с жизненными проблемами. Говорящий мысленно ставит себя на место эмпатируемого коммуниканта, демонстрируя, как бы он поступил в данной негативной ситуации.

Включение эмпатического иллокутивного компонента в директивные высказывания запрета и совета становится возможным, поскольку они аппелируют к интересам адресата и способствуют проявлению эмпатической отзывчивости. Об этом свидетельствует и одна из ключевых характеристик директивных речевых актов - бенефактивность, указывающая на уровень заинтересованности говорящего и адресата в действии, к которому каузирует высказывание, а также степень его важности.

Среди речевых высказываний, выражающих негативную реакцию, в ситуации эмпатического общения встречаются речевые акты несогласия [Архипова 2008, Боргер 2004, Норман 2020]. Исследователи относят их к одному из типов речевых актов негации, включающих такие подтипы речевых актов как иллокутивные типы «опровержение», «неодобрение», «возражение» и др. Так, в качестве реактивного высказывания на инициальное сообщение о беспокойстве адресанта по поводу потери работы, встречается речевой акт опровержения в форме утверждения класса репрезентативов.

В логике опровержение представляет собой логический процесс, включающий тезис, аргументы и демонстрацию и представляет собой рассуждение, направленное против выдвинутого утверждения с целью установления его ошибочности или недоказанности. В межличностном эмпатическом общении иллокутивным намерением предоставления информации для установления ложности 
инициального высказывания является, прежде всего, утешение, успокоение испытывающего волнения адресата. В случае если статус говорящего дружественный или имеет авторитетный посыл, стремление говорящего быть более убедительным опровергая тот или иной факт, заложенный в сообщение, иногда может быть реализовано при помощи ссылки на самого себя:

(Адресант)

-Я читал, что из-за пандемии короновируса многие могут потерять работу и сильно переживаю...

(Адресат)

-Лично я ничего такого не слышал! Значит успокойся и не переживай!

Иногда успокаивающее воздействие при опровержении негативной информации сообщаемого может сопровождаться ссылкой на опьт других людей:

(Адресант)

-Я хочу сделать прививку от короновируса, но слышал, что многие переносят ее тяжело и очень волнуюсь.

-Неправда, что все переносят прививку тяжело. Все поразному.

Еще одним речевым актом негации в ситуации эмпатической коммуникации выступает иллокутивный тип «неодобрение» также в форме репрезентативного утверждения с субъективно-оценочным компонентом. Например, в ситуации, когда говорящий жалуется на то, что нервничает, потому что не может сдать экзамен, в качестве подбадривающих реплик встречаются следующие:

(Адресант)

-Из-за волнения не могу сдать экзамен в автошколе, переживаю и плачу...

(Адресат 1)

-Это плохой настрой! Думай о хорошем и все получится!

Или

(Адресат 2)

-Зря ты так переживаешь, это того не стоит!

В межличностной коммуникации речевой акт неодобрения (как и одобрение) - это речевой акт подкласса экспрессивов на основании выражения либо отрицательной оценки говорящим адресата, либо ситуации [Головинская 1993: 196]. В ситуации 
эмпатического общения негативная оценка относится к отрицательному эмоциональному состоянию адресанта и сопровождается подбадривающей репликой в форме совета «думай о хорошем», а также высказыванием, снижающим значение события, вызывающего отрицательные переживания.

Неодобрение негативного состояния в качестве реагирующей эмпатической фразы на сообщение адресата, описывающего свои чувства после ссоры с любимым, встречается и во французском языке:

(Адресат)

-Je n'aime pas quand tu es triste à cause de cette dispute et je ne veux pas que tu te fasses des soucis pour ce conflit! / Не люблю, когда ты грустишь из-за этой ссоры и не хочу, чтобы ты переживала из-за этого конфликта!

В данном высказывании реагирующий адресат не только выражает отрицательную субъективную оценку эмоционального состояния горюющего, но и вербализует переживаемые чувства адресата (tu es triste, tu te fasses des soucis), демонстрируя степень вчувствования в его переживания.

Таким образом, речевые акты негации, а именно иллокутивныу типы «запрет», «опровержение» и «неодобрение» обладают эмпатическим потенциалом в речевой ситуации, связанной с трудностями в жизни адресата. При этом, запрещение может быть реализовано в прескриптивной форме запрета или суггестивной форме совета; опровержение эксплицировано речевым актом утверждения класса репрезентативов; неодобрение осуществляется в форме аргументативных высказываний ссылаясь на самого говорящего или на опыт других людей.

\section{ЛИТЕРАТУРА}

1. Азнабаева Л.А. Принцип вежливости в английском диалоге: монография / Л. А. Азнабаева. - Уфа: РИО БашГУ, 2005. - 198 с.

2. Архипова Е.В. Имплицитные средства выражения речевого акта согласия/несогласия в английском языке / Е. В. Архипова // Весн. Мазыр. дзярж. унта імя I. П. Шамякіна. - 2008. № 4(21). - С. 43-47. 
3. Боргер Я.В. Комплексный анализ речевых актов негативной реакции (На материале современных драматических произведений): Дис. ... канд. филол. наук: 10.02.01: - Тюмень, 2004. - 173 с.

4. https://studylib.ru/doc/2345145/-na-materialesovremennyh dramaticheskih-proizvedenij-

5. Головинская М.Я. Семантика глаголов речи с точки зрения теории речевых актов // Русский язык в его функционировании: Коммуникативнопрагматический аспект. -М.: Наука, 1993. - С. 192 217.

6. Кузнецова А.А. Иллокутивные типы вербальной эмпатии: Дис. ... канд. филол. наук: 10.02.19. Уфа, 2010. - $211 \mathrm{c}$.

7. Норман Б.Ю. Согласие и несогласие в свете теории речевых актов // Коммуникативные исследования. Том 7, № 2, 2020. - С. 300-315.

8. Переяшкина Л.Н. Когнитивный аспекты негации в языке // Университетские чтения. Материалы научно-методических чтений ПГЛУ. 2015. - С. 169-173.

9. Руссинова Т.В. Особенности функционирования запрета: на материале русского и английского языков. Автореф. дис. ... канд. филол. наук. Саратов, 2006. 22 с.

10. Трофимова Н.А. Экспрессивные речевые акты. Семантический, прагматический, грамматический анализ: монография. СПб.: Изд-во ВВМ, 2008. $376 \mathrm{c}$.

(С) Бен Шушан А.А., 2021 г. 